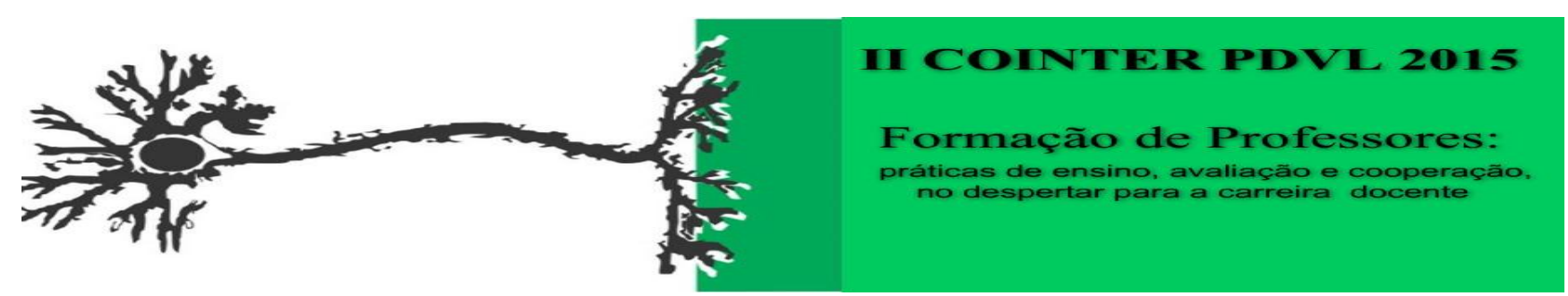

\title{
QUÍMICA APLICADA NO ENSINO, PESQUISA E EXTENSÃO: RELATO DE EXPERIÊNCIA DAS AÇÕES EMPREGADAS NA ESCOLA CPDAC
}

\author{
Apresentação: Relato de Experiência \\ Thaiane de Freitas Brito ${ }^{1}$; Bruno de Souza Vasconcelos ${ }^{2}$; Daniel Gabriel da Silva ${ }^{3}$; Flávia Rhuana \\ Pereira Sales ${ }^{4}$
}

\section{Introdução}

Em meados do século XX ao início do século XXI, a maioria dos setores de produção do nosso país foram sendo desenvolvidos, porém o sistema de ensino brasileiro, não tem acompanhado. Durante todo esse tempo, o magistério é desvalorizado com falta de investimentos, ocasionando uma realidade que versa a falta de licenciandos nas universidades. Sob esse viés, o Programa Internacional Despertando Vocações para as Licenciaturas (PDVL) tem como objetivo, desenvolver ações que auxiliem no despertar do interesse para os cursos de Licenciatura, por meio da articulação de atividades de ensino, pesquisa e extensão, tendo como foco a formação do docente.

Dentro desse contexto, o PDVL Química câmpus João Pessoa, promoveu ações com o intuito de despertar o interesse dos estudantes da Educação Básica da Escola Estadual de Ensino Médio Centro Profissionalizante Deputado Antônio Cabral (CPDAC), para o curso de Licenciatura em Química ofertado pelo Instituto Federal de Educação, Ciência e Tecnologia da Paraíba, câmpus João Pessoa.

\section{Relato de Experiência}

Ao primeiro contato foi entregue cartões em branco para cada estudante, com o intuído de contabilizar os devotados à proposta. Em seguida, um vídeo montado pela equipe tecnológica do IFPB, ilustrou as instalações do curso de Licenciatura em Química, bem como o recorte de algumas atividades que são realizadas diariamente pela equipe de discentes e docentes do Instituto. Ao fim do vídeo, o grupo expôs os benefícios e a qualidade do curso ofertado pelo IFPB, deixando espaço para o esclarecimento de dúvidas que pudessem surgir.

A abordagem foi desenvolvida a partir de uma perspectiva qualitativa, na qual Teis e Teis (2013, p. 1) afirmam que com esta "se torna promissora a possibilidade de investigação em

\footnotetext{
${ }^{1}$ Licenciatura em Química, IFPB câmpus João Pessoa, thaianefbrito@gmail.com

${ }^{2}$ Licenciatura em Química, IFPB câmpus João Pessoa, bruno15gba@hotmail.com

${ }^{3}$ Licenciatura em Química, IFPB câmpus João Pessoa, danielgabriel82@hotmail.com

${ }^{4}$ Licenciatura em Química, IFPB câmpus João Pessoa, flavia.rhuana@outlook.com
} 
pesquisas realizadas na área de educação”. Além desta, uma análise quantitativa dos discentes interessados na proposta foi realizada, com o intuito de planejar as estratégias futuras que poderão influenciar significativamente na formação dos discentes.

Após a apresentação da proposta do programa, foi possível obter uma boa perspectiva de como os estudantes da escola CPDAC pensam a respeito dos cursos de licenciatura, concomitante a ciência Química. De acordo com o Gráfico 1, aproximadamente, 73,33\% dos discentes, não se sentiram interessados pela proposta apresentada.

Gráfico 1: Nivel de aceitação do projeto pelos alunos. Fonte: Própria

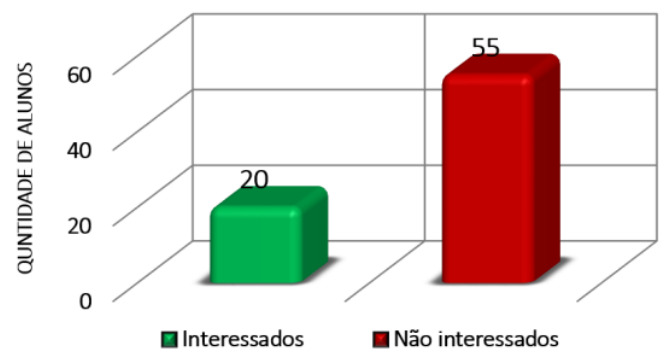

Infelizmente, algumas pesquisas, como a de Gattiet al (2014) e Silva et al (2010) nos mostra que essa realidade não é reservada à escola CPDAC. Os estudiosos informam que a rejeição pela licenciatura advém de questões socioeconômicas, uma vez que há uma desvalorização dos docentes, que por sua vez, possuem longas jornadas de trabalho e baixo salário, tendo como corolário, altos níveis de estresse, pois necessitam ensinar em mais de um turno.

\section{Considerações}

A ação que ocorreu no CPDAC foi de extrema relevância, visto que possibilitou observar naquele espaço amostral os estudantes interessados em participarem das propostas e ações ativas. Dessa forma, como alvitre para 2015.2, o PDVL Química conduzirá estes alunos para conhecer as instalações do Curso de Licenciatura em Química, como por exemplo, os laboratórios, salas de aula, bem como os projetos oferecidos pelo curso, os quais desenvolvem Ensino, Pesquisa e Extensão.

\section{Referências}

GATTI, B. A;TARTUCE, L.P.B; NUNES, M.M.R;ALBIERI DE, A. P;. A atratividade da carreira docente no Brasil. Sao Paulo, 2014 : Fundação Victor Civita.

SILVA, R. O.; ALCÂNTARA, B. F.; JÚNIOR, J. G. T. A Química e os alunos do Ensino médio: uma investigação realizada por estagiários comprometidos com a melhoria do ensinoaprendizagem. In:XV Encontro Nacional de Ensino de Química (XV ENEQ) - Brasília-DF,2010.

TEIS, D. T.; TEIS, M. A. A Abordagem Qualitativa: a leitura no campo de pesquisa. Disponível em http://www.bocc.ubi.pt. Acesso em 16 junho 2015. 